21. Fromm, E. (2006). Man for Himself. Moscow: Ast [in Russian].

22. Horuzhenko, K. (1997). Culturology. Encyclopedic dictionary. Rostov-onDon: Feniks [in Russian].

23. Shlifstein, S. (1961). S. S. Prokofiev: materials, documents, memories. Moscow: State musical publishing house [in Russian].

Стаття надійшла до редакції 28.06.2017

УДК 78.03+78.021/78.071.1＜noBreak> DOI: 10.31723/2524-0447-2017-25-202-214

\author{
Анна Дмитрівна Стоянова \\ https://orcid.org/0000-0002-3092-1922 \\ здобувач кафедри історії музики \\ та музичної етнографіі \\ Одеської національної музичної \\ академії ім. А. В. Нежданової \\ Flame.reddik@gmail.com \\ Magali57@rambler.ru

\section{ЯВИЩЕ СОЛІЛОКВІУМА У СУЧАСНІЙ КОМПОЗИТОРСЬКІЙ ТВОРЧОСТІ: ДО ПОСТАНОВКИ ПРОБЛЕМИ}

Метою дослідження є розгляд проблеми солілоквіума як форми особливого внутрішнього діалогу у сучасній композиторській творчості, визначення місия $і$ значення солілоквіума в музиці. Методологія статті грунтується на узагальненні досліджень проблеми солілоквіума у мистецтвознавчих роботах. Використовується аналітичний підхід до концепції внутрішнього мовлення стосовно ї̈ проекції на твори мистецтва, наводиться порівняльна характеристика діалогу та самодіалогу. Наукова новизна обумовлена тим, що в статті вперше здійснюється різнобічна аналітична характеристика явища солілоквіума в різних видах мистецтва, дається розгорнуте визначення місия солілоквіума в музиці. Висновки. Солілоквіум в музиці стає естетичною парадигмою, яка обростає композиційними прийомами, тобто він не локалізуеться в одній жанровій формі, але визначає жанровий спосіб творчості, породжуючи певні композиційні рішення. Музичний солілоквіум формує власну семантичну сферу, пов'язану як з діалогічними прийомами, так $і$ зі стильовою єдністю музичного матеріалу, тобто виступає як еквівалент авторського монодіалогу.

Ключові слова: солілоквіум, самодіалог, види діалогу, внутрішне мовлення, музичний солілоквіум. 
Stoianova Anna, applicant of the department of music history and musical ethnography of Odessa National A. V. Nezhdanova Academy of Music

The phenomenon of soliloquium in contemporary composer creativity: to the formulation of the problem

The purpose of study is to examine the problem of soliloquium as a form of a special internal dialogue in contemporary composer creativity, definition of place and meaning of soliloquium in music. The methodology of the article is based on the generalization of soliloquium problem in art criticism studies. An analytical approach is used for the concept of internal speech in relation to its projection on works of art, a comparative characteristic of dialogue and self-dialog is given. The scientific novelty is based on the fact that in the article a multifaceted analytical description of the phenomenon of soliloquium in different types of art is carried out, and a detailed definition of the place of soliloquium in music is given for the first time. Conclusions. Soliloquium in music becomes an aesthetic paradigm that overgrows with compositional techniques, it does not localize in one genre form, but determines genre inclination of creativity, generating certain compositional solutions. Musical soliloquium forms its own semantic sphere, connected both with dialogical methods, and style unity of musical material, it acts as an equivalent of the author's mono-dialog.

Keywords: soliloquium, self-dialog, types of dialogue, inner speech, musical soliloquium.

Стоянова Анна Дмитриевна, соискатель кафедры истории музыки и музыкальной этнографии Одесской национальной музыкальной академии им. А. В. Неждановой

Явление солилоквиума в современном композиторском творчестве: $\boldsymbol{\kappa}$ постановке проблемы

Целью исследования является рассмотрение проблемы солилоквиума как формы особого внутреннего диалога в современном композиторском творчестве, определение места и значения солилоквиума в музыке. Методология статьи строится на обобщении исследований проблемы солилоквиума в искусствоведческих работах. Используется аналитический подход к концепиии внутренней речи по отношению $к$ ее проекиии на произведения искусства, приводится сравнительная характеристика диалога и самодиалога. Научная новизна обусловлена тем, что в статье впервые осуществляется разносторонняя аналитическая характеристика явления солилоквиума в разных видах искусства, дается развернутое определение места солилоквиума в музыке. Выводы. Солилоквиум в музыке становится эстетической парадигмой, которая обрастает композиционными приемами, то есть он не локализуется в одной жанровой форме, но определяет жанровое наклонение творчества, порождая определенные композиционные решения. Музыкальный солилоквиум формирует собственную семантическую сферу, связанную как с диалогическими приемами, так и со стилевым един- 
ством музыкального материала, то есть выступает как эквивалент авторского монодиалога.

Ключевые слова: солилоквиум, самодиалог, виды диалога, внутренняя речь, музыкальный солилоквиум.

Актуальність обраної теми полягає в тому, що, незважаючи на те, що проблема солілоквіума як форми особливого внутрішнього діалогу була поставлена ще в працях античних філософів, вона і досі допомагає розкривати можливості словесної творчості. Солілоквіум $€$ засобом розвитку та представлення самосвідомості шляхом раціоналізації діалогу, а самодіалог є неодмінною частиною будь-якої діалогічної форми. Саме виведення назовні (експлікація) внутрішнього діалогу стає специфічною жанровою формою як усної, так і письмової мови.

Метою дослідження є розгляд проблеми солілоквіума як форми особливого внутрішнього діалогу у сучасній композиторській творчості, визначення місця і значення солілоквіума в музиці.

Викладення основного матеріалу.

Проблема солілоквіума як форми особливого внутрішнього діалогу була поставлена ще в працях античних філософів. Ї̈̈ основою було вивчення можливостей словесної творчості, тобто пізнавально-оцінювальних функцій слова як інструменту людської свідомості. Виведення назовні (експлікація) внутрішнього діалогу стало специфічною жанровою формою як усної, так і письмової мови.

Звернення до солілоквіума починається діалогами Сократа і завершується «Розмовою з розумом» Августина. Останній відкриває поняття «людини внутрішньої», тобто доступної не пасивному самоспостереженню, а тільки активному діалогічному підходу до себе самої, що призводить до переосмислення ліричного, епічного і трагічного образу людини.

Саме активний діалогічний підхід до себе самого стає головною особливістю солілоквіума, яка відокремлює його від самосвідомості та рефлексії. Так, на відміну від самосвідомості, солілоквіум є навмисно та спеціально організованою формою експлікації змісту, що виражає волю особистості. Його внутрішня активність пробуджує творчі здібності свідомості, висловлює іiї прагнення «дістатися» до раціонально-логічної форми. На відміну від рефлексії, солілоквіум пробуджується зовнішніми питаннями, йому повинні передувати зовнішні завдання (певна зовнішня здивованість): спочатку народжується питання, а потім відшукується відповідь на нього. 
Для того, щоб більше заглибитися у природу солілоквіума, звернемося до деяких його визначень в мистецтвознавчих роботах. Так, наприклад, Генріх Буш в авторефераті своєї дисертації «Творчество как диалогическое взаимодействие» пише: «Каждый индивид в процессе социализации приобретает способность вести внутренний диалог с самим собой - солилоквиум, выражая свою внутреннюю свободу и неотчуждаемую субъективность. Понимание сущности этого микродиалога между логической и эмоциональной сферами сознания, между сознанием и бессознательным позволяет раскрыть роль догадки в творчестве и выявить возможности управления эвристической интуицией» [5, 18].

За словами Михайла Бахтіна, солілоквіум «разбивает внешние оболочки образа себя самого, существующие для других людей, определяющие внешнюю оценку человека (в глазах других) и замутняющие чистоту самосознания» [4, 135-136].

Цікавий погляд на проблему солілоквіума представляє Ентоні Шефтсбері в роботі «Солилоквия или совет автору» [10]. Він згадує про знаменитий напис в Дельфах «Пізнай себе», трактуючи його як «раздели себя, будь двумя» $[10,343]$. Цей поділ і є солілоквією, яка, за словами Шефтсбері, як здатність підтримувати свою внутрішню бесіду, була особливою рисою філософів та мудреців. Дослідник пише: «И они гордились здесь тем, что никогда не бывали менее одиноки, как оставаясь наедине с собою. Ибо человек низкий, полагали они, никогда не бывает с собою и при себе» [10, 343].

Таким чином, Ентоні Шефтсбері вважає, що завдяки солілоквії людина отримує можливість критично пізнавати себе, з чого починається їі моральне вдосконалення. Крім цього, автор у зв'язку з солілоквією говорить про необхідність самовиховання, що є важливою установкою античної думки. Тут потрібно відзначити, що в античності солілоквіум навчав самовихованню та пробуджував здатність до діалогу через можливість почути голос власного розуму, який не належить тільки людині.

У римських стоїків солілоквіум був безпосередньо пов'язаний з вченням про вдосконалення душі (психогогікою), або своєрідне «лікування душі». Поняття «психогогіка» було введено Сенекою, який сприймав філософію як свого роду психотерапію, що використовує такі методи, як самоспостереження, розмова з самим собою (солілоквіум); роздум про передбачувані біди (паренеза); моральна проповідь (діатриба); розрада; молитва. 
Звернемося до визначення місця та значення солілоквіума в загальній системі діалогу. Необхідно відзначити, що внутрішній діалог усвідомлюється тоді, коли він озвучений (тобто необхідно його конкретизувати, знайти засоби внутрішнього мовлення для його вираження). Вербалізація - це один з необхідних елементів мовної організації внутрішнього діалогу (вона дозволяє визначити позиції особистості відносно того чи іншого явища). Вербальні оцінки можуть бути чи не бути домінантними, але для музичних образів їх «називання» необхідно як спосіб раціоналізації.

Таким чином, коли потрібно представити зміст самодіалогу свідомості, є необхідність в засобах раціоналізації. Можна сказати, що в такому випадку залучається і загально-комунікативний досвід організації діалогу, що передбачає розподіл діалогу за видами і типами.

Так, О. Самойленко у монографії «Музыковедение и методология гуманитарного знания. Проблема диалога» [8], спираючись на концепцію Бахтіна, вирізняє наступні види діалогу:

1) діалог з традицією культури в цілому, зі спільнотою, з «авторитетом» (можливий, перш за все, як діалог згоди);

2) міжособистісний як міжавторський діалог, що допускає зустрічність суджень, навіть чекає іiі (діалог незгоди);

3) міжіндивідуальний, заснований на граничному взвуженні і «закритості» точок зору обох учасників, що створює рух смислової розбіжності - взаємне віддалення, аж до «нечутності» висловлювань, незважаючи на їх «гучність», яскраву демонстративність (діалог глухих);

4) міжобщинний, міжсуспільний (міжкультурний, міжавторитетний), який, втім, може бути репрезентований як міжособистісний, у разі анонімності особистості - не-претензії на авторську участь (діалог мовчання або, як писав М. Бахтін, «діалог мертвих»).

Проблема типології діалогу залишається актуальною і для сучасних дослідників та розробляється досить активно. Зокрема з'являється поняття «внутрішньої мови» або інтраперсонального спілкування. Так, наприклад, в дисертації Юлії Сергєєвої «Внутренняя речь как особая форма языкового общения (на материале англоязычной художественной литературы)» [9] вирізняються п'ять можливих типів інтраперсонального спілкування:

1. Реально існуючі особи, відокремлені від індивідуума простором.

2. Особи, які пішли з життя до моменту інтраперсонального спілкування. 
3. Діалог з потенційним співрозмовником - реально існуючою особою, яка перебуває в момент спілкування поряд з індивідуумом, але $є$ для нього небажаним або недоступним партнером для комунікації.

4. Діалог з уявним співрозмовником. До уявних співрозмовників автор дисертації відносить наступні групи об’єктів:

а) одухотворені об'єкти - тварини, птахи, риби і т. д.;

б) неживі об’єкти - конкретні предмети;

в) абстрактні поняття;

г) явища природи;

д) міфічні особистості, літературні герої.

5. Діалог з нададресатом, в якості якого виступають Бог, Богоматір, вища сила, Абсолют і т. д. До цього типу інтраперсонального спілкування належать в основному фідеїстичні тексти - молитви, гімни, конвенціальні формули. Тут автор дисертації звертається до однієї з центральних категорій діалогічних відносин в розумінні Михайла Бахтіна - категорії нададресата. За словами М. Бахтіна, «автор высказывания с большей или меньшей осознанностью предполагает высшего нададресата (третьего), абсолютно справедливое ответное понимание которо[го] предполагается либо в метафизической дали, либо в далеком историческом времени... (Бог, абсолютная истина, суд беспристрастной человеческой совести, народ, суд истории, наука и т. п.)» $[3,498]$.

Автор дисертації поділяє співрозмовників цього типу на дві групи:

1) аутодіалог або солілоквіум, адресатом якого виступає «друге Я» індивідуума;

2) діалог з відсутнім співрозмовником, який завжди є реально існуючою особою.

Таким чином, можна сказати, що солілоквіум є засобом розвитку та представлення самосвідомості шляхом діалогу (раціоналізації діалогу), а самодіалог є неодмінною частиною будь-якої діалогічної форми, так само як самосвідомість є обов'язковою частиною свідомості.

Щоб простежити, як проектується концепція внутрішнього мовлення на твори мистецтва, необхідно, в першу чергу, з'ясувати, як в мистецтві розрізняються діалог та самодіалог (оскільки в будь-якому пізнавально-оцінювальному, а, значить, і творчому процесі присутнім $€$ і те, й інше). В процесі написання художнього твору автору необхідно, по-перше, спиратися на існуючий творчий досвід, по-друге, 
оволодіти загальним контекстом епохи. Таким чином відбувається діалог з традицією, з іншими авторами, з уже створеними зразками. Однак головною складовою творчості є безпосередньо створення власних творів, а для цього автору необхідно оволодіти власною свідомістю, тобто звернутися до солілоквіума як до творчого процесу.

Таким чином, можна відзначити, що в мистецтві поняття солілоквіума існує в двох видах: як процес створення і як його результат (тобто як текст художнього твору).

Процес написання художнього твору завжди є солілоквіумом, тому що, здійснюючи пошук творчих ідей, автор звертається до самого себе з низкою запитань («Що я хочу написати?», «Що я хочу сказати?», «Які засоби я буду використовувати?»). А успішне завершення цього процесу можливе тільки тоді, коли відповіді на всі питання будуть отримані. Іншими словами, в якості питань виступають творчі інтенції автора, а місцем «збирання» результату є його власна свідомість, у якій він шукає відповіді.

Що стосується солілоквіума як тексту художнього твору, можна навести безліч прикладів в кожній галузі мистецтва. Ми зустрічаємо солілоквіум і в театрі, і в літературі, і в живописі, і в музиці, причому в кожному з випадків він реалізується інакше. Варто відзначити, що він може реалізовуватися як в масштабі цілого твору, так і в якості його частини або розділу.

У театрі солілоквіум представляється найяскравіше - ми на власні очі бачимо героя, який входить в діалог із самим собою. Один 3 найбільш характерних прикладів солілоквіума як частини спектаклю - це шекспірівський «Гамлет», в якому ми бачимо, як герой, щоб вивести себе зі стану депресії і змусити діяти тверезо та продумано, починає викривати себе в слабкості та нерішучості (саме це зображено Шекспіром в монологах-солілоквіумах Гамлета). Гамлетівський солілоквіум можна трактувати також як «діалог глухих» (за класифікацією О. Самойленко), причому для героя суперечливість власної свідомості стає критерієм оцінки світу.

Що стосується цілісного прояву театрального солілоквіума, то таким є моноспектакль, в якому один герой може не тільки представляти діалогічне ставлення до себе, але і сольно розкривати всю навколишню дійсність (наприклад, «Людський голос» Жана Кокто).

Подібним чином солілоквіум втілюється і в літературі. Тут можна відзначити, що цілісне звернення до цього виду діалогу ми зустрічаємо, як правило, в малих жанрах, особливо в віршах (яскравий при- 
клад - «Диалог Гамлета с совестью» Марини Цвєтаєвої). А ось всередині великого жанру солілоквіуми з'являються в ключові, навіть переломні для героя моменти, як, наприклад, в романах Федора Достоєвського. Для сучасної літератури цікавою особливістю стає включення слова «солілоквіум» в назву або жанровий підзаголовок твору: Олександр Морозов «Общая тетрадь. Солилоквиум» (1975), Марина Саввіна «Люди картонного города, или Солилоквиум в начале конца света. Роман-цитата» (2006).

Найважче говорити про солілоквіум в образотворчому мистецтві, однак тут можна припустити, що він досить повно розкривається в тих випадках, коли автор зображує самого себе, таким чином втілюючи діалогічне ставлення до себе. Якщо розглядати солілоквіум як дію, що триває у часі, то в живописі він втілюється через створення художником серії автопортретів (наприклад, серія автопортретів Вінсента ван Гога).

Солілоквіум як акт самосвідомості, самооцінки в музиці втілюється особливим чином, тому що будь-яка музика має стиль, будь-який стиль - це вся людина, а будь-яка людина як ціле - це людина, що володіє самосвідомістю.

Музичний солілоквіум, можна сказати, вбирає в себе особливості його втілення у всіх інших видах мистецтва: театральний аспект втілюється в опері, літературне звернення до себе розкривається в інструментальній музиці, солілоквіуми-автопортрети, які стосуються образотворчого мистецтва, зустрічаються в музиці у вигляді монограм або автоцитат.

Стилістично музичний солілоквіум найбільш близький мінімалізму, причому кожен з композиторів, які працюють в цьому напрямку, знаходить своє втілення через звернення до різних засобів музичної виразності. Так, наприклад, у Валентина Сильвестрова солілоквіум (як погляд на свідомість, в тому числі і музичну свідомість, зсередини) реалізується через пошук музичних знаків, які є основою музичної свідомості. Він задається питанням, з чого формується свідомість музиканта, намагаючись знайти відповідь у зверненні до досягнень попередніх епох. Зовсім інакше трактує музичний солілоквіум Лучано Беріо, який прагне залучити до процесу самодіалогу саму музику в процесі стилізації, колажування, маніпуляції фрагментами чужих текстів. Тобто, якщо питання В. Сильвестрова стосується моменту формування музичної свідомості, то питання Л. Беріо стосується іiі безпосереднього наповнення, iii активної діяльності. 
Третю позицію відносно до музичного солілоквіума представляє творчість Гії Канчелі з його медитативністю, прагненням до самообмеження. Це прагнення виражається через граничну економію засобів виразності, яка доходить до стану гучної тиші (коли тиша, тиха динаміка сприймається як знак входження в особливий внутрішній стан - стан продуктивної самотності).

Г. Канчелі створює своего роду «незвучащий временной континуум музыки» (термін Михайла Аркадьєва [1]). Цей термін Аркадьєв виводить з опозиції «гучної» (неакустичної) та «не-гучної» матерії в музиці, яку представляє як аналогічну опозиції «простір-маса» в архітектурі. Цікаво відзначити, що він вважає «негучний», часовий континуум в музиці більш активним і складно організованим в порівнянні з порожнім архітектурним простором.

Саме шлях протиставлення гучного та негучного матеріалу, причому з особливим акцентом на моментах тиші, представляється найбільш наближеним до знаходження справжніх відповідей на ті питання, які і стали для суб'єкта причиною солілоквіума. На думку О. Самойленко, істина в будь-якому діалозі (в тому числі і самодіалозі) народжується саме в паузах, в моментах «тиші», яким протиставляється відособленість та структурна завершеність окремих висловлювань, що входять в діалог. О. Самойленко пише: «Целостность высказывания, позволяющая находить в нем семантическую завершенность, и осмысливающее молчание как дистанция между высказываниями являются условиями диалога и, соответственно им, катартическими условиями художественного (музыкального) диалога» [8, 173].

Ця думка знаходить підтверження у словах Михайла Бахтіна: «Молчание - осмысленный звук (слово) - пауза составляют особую логосферу, единую и непрерывную структуру, открытую (незавершимую) целостность» $[2,357]$. В цьому спостереженні М. Бахтін повертається до провідної в його поетиці понятійної діалогічної «пари»: завершеність - відкритість, оскільки «осмислене слово» - висловлювання - для нього існує в двох планах: як завершене, висловлювання є неповторним, а як долучене до мови - повторюваним, отже відкритим.

Застосовуючи сказане М. Бахтіним у характеристиці музично-творчого процесу, О. Самойленко зазначає, що «в первом случае, на наш взгляд, высказывание существует как внутрикомпозиционный феномен, то есть в контексте художественного произведения. Во втором оно адресуется текстологическим уровням развития музыки» $[8,173]$. 
Взаємодію «першого та другого вона називає, слідом за М. Бахтіним, «музыкальной логосферой» - общим логосом («самовозрастающим») музыки» [8, 173], підтверджуючи свої слова наступною цитатою М. Бахтіна: «Через высказывание язык приобщается к исторической неповторимости и незавершенной целостности логосферы» $[2,357]$.

Поняття солілоквіума в музиці також може бути пов'язане з тенденцією камернізації (солілогізації) великих жанрів - симфонії та опери, яка відбувається у композиторській творчості на сучасному етапі.

Відносно симфонії можна відзначити, що, незважаючи на те, що раніше цей жанр виступав як репрезентативний і був орієнтований на соціально значущі «великі» образи, останнім часом відбувається процес його камернізації з метою передачі в музиці внутрішнього світу людини.

Що стосується жанру опери, то посилення його камерності, так само як і в симфонії, пов'язане з поглибленням у власні межі, що призводить до посилення інтенціональних чинників. У вокальній музиці ця тенденція часто виявляється пов'язаною з діалогом між поетом і композитором, який претендує вже на рівень «діалогу культур».

Яскраве втілення симфонічного солілоквіума - сім симфоній Гії Канчелі. Композитор не вдається до традиційних симфонічних принципів, а створює свій стиль, навіть свій тип симфонізму, при якому всі симфонії подібні одночастинним поемам з варіантно-варіаційним розвитком і контрастним образним змістом.

Об’єднуючим фактором для всіх симфоній Г. Канчелі служить вільна поемність розгортання задуму композитора, а також розповідь «від першої особи» і висунення на перший план суб'єктивного начала. В цьому і проявляється «солізація» симфонізму, а явище самодіалогу реалізується в симфонічному методі Г. Канчелі через зіставлення двох образних сфер - FF і РP. Саме завдяки різким і раптовим зіставленням створюється відчуття реального внутрішнього діалогу, причому такого, що відбувається на високому емоційному напруженні.

Як приклад симфонічного солілоквіума можна навести початок П’ятої симфонії Г. Канчелі. Тут у внутрішньому діалозі сходяться два протилежних начала: «дитяча» лейттема клавесина (секвенції, навіяні музикою бароко, що сприймаються як щось незворотне, інфантильне) та скорботна тема, що вторгається до неї - вона знаходить себе в неясних інтонаційних відблисках, в низхідних «стогонах» оркестру. Цей 
солілоквіум стає відправною точкою розвитку всього твору - 3 нього виростають всі основні теми, а висновок симфонії $є$ і його підсумком.

Солілоквіум П'ятої симфонії з його заглибленням у себе виростає 3 того, що Наталя Зейфас називає «кризисом поэтического мироощущения» $[6,91]$. За ііі словами, саме до цього рубежу, що визначився наприкінці 70-х років у всьому грузинському мистецтві, приходить «музыкальная драматургия Канчели в Пятой симфонии» $[6,91]$.

Як приклад оперного солілоквіума в двох його варіантах - у вигляді діалогізованного монологу та у вигляді монологізованного діалогу - можна навести моноопери В. Губаренка «Листи кохання» («Ніжність») та «Монологи Джульєтти».

Аналізуючи ці моноопери у своїй кандидатській дисертації, Ольга Лісова пише: «В моноопере «Письма любви» структурной и смысловой основой композиции выступает диалогизированный монолог, вернее, действует правило диалога отождествления, когда двое думают в реальности или в воображении одно и то же. А в «Монологах Джульетты» реализуется идея монологизированного диалога, то есть растождествленного монолога, когда сознание героини своеобразно раздваивается, находит свою внутреннюю оппозицию, звучит на два разных голоса. Отсюда и внешне парадоксальное название - «Монологи» - для оперы, в которой участвуют двое действующих лиц Джульетта и падре Лоренцо» [7, 83].

Незважаючи на те, що в «Листах кохання» задіяний один сценічний персонаж, а в «Монологах Джульєтти» - два, обидва ці твори за своєю сутністю є монообразними. Однак в той же час образ, що розкривається в них, є двоїстим, він поєднує протилежні смислові та інтонаційні начала; при цьому в ньому присутні і загальні наскрізні тематичні елементи. Тобто можна говорити про те, що обидві ці опери стають солілогізованими. На це вказує також і те, що оркестрова та вокальна партії діалогічно доповнюють одна одну, композитор чергує їх, представляє у вигляді контрапункту, досягаючи тим самим нероздільної єдності двох музично-виконавських оперних сфер.

Також композитором в обох цих операх реалізується ідея одвічного діалогічного протистояння Рока та людини. Вона втілюється у музично-тематичному змісті опер через протиставлення полярних комплексів любові та смерті, при цьому в обох творах композитор представляє можливість катартичної розв'язки.

Проведене дослідження жанрово-стильового розмаїття солілоквіума в музиці дозволяє сформулювати наступні висновки. 
Солілоквіум в музиці стає естетичною парадигмою, яка обростає композиційними прийомами, тобто, він не локалізується в одній жанровій формі, але визначає жанровий спосіб творчості (як, наприклад, тенденцію камернізаціi), породжуючи певні композиційні рішення. Як форма художнього самодіалогу в музиці він стає необхідною складовою композиторської поетики, передбачає різноманіття композиційних та стилістичних засобів втілення й розвитку, виявляє залежність від стильових настанов музичного мистецтва та його семантичних пріоритетів.

Таким чином, можна говорити про те, що музичний солілоквіум формує власну художньо-виразову сферу, пов'язану як з діалогічними прийомами, так і зі стильовою визначеністю музичного матеріалу, виступає як еквівалент авторського композиторського монодіалогу.

\section{СПИСОК ЛІТЕРАТУРИ}

1. Аркадьев М. Временные структуры новоевропейской музыки: Опыт феноменологического исследования. М.: Библос, 1992. 168 с.

2. Бахтин М. Из записей 1970-1971 годов. Бахтин М. Эстетика словесного творчества [сост. С. Бочаров; прим. С. Аверинцева и С. Бочарова]. [2-е изд.]. М.: Искусство, 1986. С. 355-380.

3. Бахтин М. Проблема текста в лингвистике, филологии и других гуманитарных науках. Опыт философского анализа. Литературно-критические статьи. М.: Художественная литература, 1986. С. 473-500.

4. Бахтин М. Проблемы поэтики Достоевского. М.: Советский писатель, 1963. $363 \mathrm{c}$.

5. Буш Г. Творчество как диалогическое взаимодействие: автореф. дис. ... доктора филос. наук: спец. 09.00.01 - Диалектический и исторический материализм. Минск, 1989. 28 с.

6. Зейфас Н. Симфонии Г. Канчели. Композиторы союзных республик : [сб. статей]. М.: Советский композитор, 1980. Вып. 3. С. 49-93.

7. Лисовая О. Программность как жанровая парадигма камерной вокальной музыки: к проблеме исполнительского понимания: дис. ... кандидата искусствоведения: спец. 17.00.03 - Музыкальное искусство. Одесса, 2009. $199 \mathrm{c}$.

8. Самойленко А. Музыковедение и метолодогия гуманитарного знания. Проблема диалога: монография. Одесса: Астропринт, 2002. 244 с.

9. Сергеева Ю. Внутренняя речь как особая форма языкового общения (на материале англоязычной художественной литературы): дис. ... доктора филол. наук: спец. 10.02.04 - Германские языки. М., 2009. 565 с.

10. Шефтсбери А. Солилоквия, или Совет автору. Эстетические опыты. М.: Искусство, 1975. С. 332-457. 


\section{REFERENCES}

1. Arkadev M. (1992) Time structures of the New-European music: The experience of phenomenological research. M.: Byblos. [in Russian].

2. Bakhtin M. (1986) From the records of 1970-1971// Aesthetics of verbal creativity [comp. by S. Bocharov. Note. by S. Averintsev and S. Bocharov]. [2 nd ed.]. M.: Art. [in Russian].

3. Bakhtin M. (1986) The problem of text in linguistics, philology and other humanities. Experience of philosophical analysis // Literary-critical articles. M.: «Imaginative literature». [in Russian].

4. Bakhtin M. (1963) Problems of Dostoevsky's poetics. Moscow: Soviet writer. [in Russian].

5. Bush G. (1989) Creativity as a dialogical interaction: the author's abstract: diss. for the degree of Doctor of Philosophy. Sciences: spec. VAK RF 09.00.01 «Dialectical and historical materialism». Minsk. [in Russian].

6. Zeifas N. (1980) Symphonyes by G. Kancheli // Composers of the Union Republics: [Sat. articles]. Moscow: Soviet composer. Issue 3. [in Russian].

7. Lisova O. (2009) Programmness as a genre paradigm of chamber vocal music: to the problem of performing understanding: diss. for the degree of Candidate of Art Criticism: spec. VAK 17.00.03 «Musical Art». Odessa. [in Russian].

8. Samoylenko A. (2002) Musicology and metodology of humanitarian knowledge. The problem of dialogue: Monograph. Odessa: Astroprint. [in Russian].

9. Sergeeva Y. (2009) Inner speech as a special form of language communication (on the material of English-language imaginative literature): diss. for the degree of Doctor of Philology. Sciences: spec. VAK 10.02.04 «Germanic languages». M. [in Russian].

10. Shaftesbury A. (1975) Soliloquy, or, Advice to an author // Aesthetic experiments. Moscow: Art. [in Russian]. 